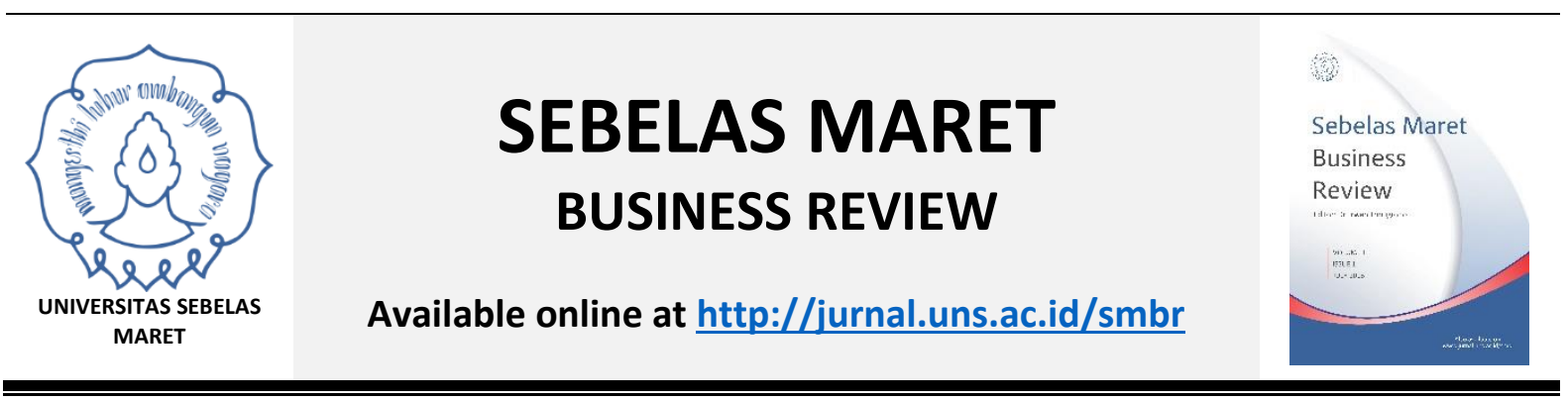

\title{
BIOSECURITY ADOPTION OF BEEF CATTLE FARMERS
}

\section{Veronica Sri Lestari' ${ }^{1}$, Sitti Nurani Sirajuddin, Agustina Abdullah}

Faculty of Animal Science, Jl. Perintis Kemerdekaan Km 10, Makassar 90245, Indonesia

${ }^{1}$ Corresponding author: veronicasrilestari@unhas.ac.id

\begin{tabular}{ll} 
ARTICLE INFO & ABSTRACT \\
\hline Article History: & $\begin{array}{l}\text { The main objective of this research is to find the level of } \\
\text { biosecurity adoption by beef cattle farmers. This research }\end{array}$ \\
$\begin{array}{l}\text { Received 30 November } \\
\text { is conducted in Luwu regency, South Sulawesi, Indonesia. } \\
2017\end{array}$ & $\begin{array}{l}\text { The data are collected from observation and interview } \\
\text { using questionnaire. The sample is } 31 \text { beef cattle farmers }\end{array}$ \\
$\begin{array}{l}\text { Accepted 4 December } \\
2017\end{array}$ & $\begin{array}{l}\text { who are selected using random sampling. There are } 35 \\
\text { questions in the questionnaire that consist of management } \\
\text { practice, sanitation, equipment, disease and disease } \\
\text { Feblable online 3 }\end{array}$ \\
prevention, and calf management. The data are analyzed \\
descriptively using frequency distribution. The results \\
revealed that the level of biosecurity adoption is $69.3 \%$, \\
and it is categorized as "high adopters".
\end{tabular}

Beef cattle farmers,

Biosecurity

\section{INTRODUCTION}

Beef cattle have an important role as a source of animal protein. The Indonesian government has to imported beef from other countries, such as Australia and New Zealand, because domestic production cannot fulfill the local demand. Ministry of Agriculture statistics highlight that the volume of imported beef during 2015 reached 50 thousand tons. The imported commodities including non-bone cut meat, carcass and half carcass, boneless meat, and preserved meat. The Indonesian government, in fact, has provided some innovative technologies to increase meat production, such as Artificial 
Insemination (AI), Embryo transfer, Urea Molasses Block, and Complete Feed. There is also a technology to prevent beef cattle from diseases, that is, biosecurity.

Biosecurity is essential to prevent disease transmission among animals in the farms as well as from farm to farm (Sahlstrom et al., 2014). Most producers felt that the nominated biosecurity practices were in some way useful. However, there was not always agreement between the usefulness of practice and undertaken, and vice versa (Brennan and Christley, 2013). Farm biosecurity protects the health of cattle by preventing the introduction and transmission of disease agents to the farm. A successful biosecurity plan should cover three main areas: isolation, traffic control, and sanitation. The most crucial step in disease control is minimizing the movement of cattle. This is especially important for new animals arriving at the farm. Consider the points where diseases could enter a farm or ranch and the pathways by which the disease spreads. This is especially important for smaller, more confined operations and feedlots where traffic is coming and going in different directions. The sanitation component of a biosecurity plan aims to prevent contamination of cattle and equipment.

In the first edition of seminal book Diffusion of Innovations, (Rogers, 1962) conceptualized the adoption process as awareness, interest, evaluation, trial, and adoption. Based on this statement we may state that innovation adoption is similar to the decision-making process to acquire innovation or a decision to continue using the innovation at full-scale.

According to Suparta and Sukanata, 2017, the characteristics of the beef cattle industry in Indonesia are: small-scale ownership, keeping cattle on a sustainable basis, raising cattle as life savings, keeping cattle in densely populated settlements and a planted fields or behind homes, having limited space for treatment. Other characteristics are that thus their feed is often to be sought outside the enclosure, livestock farming is done traditionally, and some farmers do not have enough capital to buy breed beef cattle.

Walenrang sub-district is one of the districts in Luwu regency with 1,229 beef cattle population. According to Azis (2016), Luwu Regency is located in the South Sulawesi structured within the development of beef cattle. In general, cattle are cultivated in the hope that beef cattle are protected from the contagious or infectious diseases. However, according to Nuruddin (2016), in the last ten years, Anthrax case occurred in Sulawesi regencies and one of them is in Luwu regency, after Bulukumba, Takalar, Gowa, Bone, Maros, Pangkep, Barru, Sidrap, Pinrang, Pare-Pare, and Makassar.

The purpose of this research, therefore, is to find the level of biosecurity adoption by beef cattle farmers in the district Luwu Regency, Indonesia.

\section{RESEARCH METHOD}

The population of this research is 99 beef cattle farmers in Luwu regency, South Sulawesi province. The total sample is 31 people. The sample is selected through random sampling. Data are collected through observation and in-depth interview using questionnaire. There are 35 questions which consist of the application of good management practice, sanitation, equipment, diseases, diseases prevention, and calf management. Guttman scale is used in this research if the answer is YES the score is 1 , if the answer is NO, the score is 0.

The level of biosecurity adoption is calculated using adoption index (Karthikeyan, 1994 in Rahman, 2007): 


$$
\text { Adoption Index }=\frac{\text { respondent total score }}{\text { total possible score }} \times 100
$$

Depending upon the extent of adoption of biosecurity measures, the respondents are categorized as follows:

(1). Low adopter (up to 33\%)

(2). Partial adopters (34-66\%)

(3). High adopters $(67-100 \%)$

\section{RESULTS AND DISCUSSION}

\section{Characteristics of beef cattle farmers}

The characteristic of beef cattle farmers can be seen in Table 1 . The majority of respondents are male. On average, the respondents are less than 50 years old. This indicates that they are in productive age. They are still strong enough to take care of their beef cattle. According to their education, on average respondents spent more than seven years in school, meaning that they have finished their elementary school. In other words, respondents are literate. Regarding family size, on average respondents came from small family. Looking at the number of beef cattle, on average respondents have four cattle. On average the respondents have around ten years experiences in beef cattle farming. The average distance between respondent's house and cowshed is 6.3 meters; this condition is not ideal because according to Sihombing (2000), the minimum distance between cowshed and farmer's house should be 250 meters.

Table 1. Characteristics of Beef Cattle Farmers

\begin{tabular}{llllll}
\hline Item & Minimum & Maximum & Mean & $\begin{array}{l}\text { Standard } \\
\text { Deviation }\end{array}$ & Percentage \\
\hline Sex & & & & & \\
$\quad$ a. Male & & & & 83.87 \\
$\quad$ b. Female & 29.0 & 74.0 & 43.49 & 11.598 & 16.13 \\
Age (year) & 6.0 & 12.0 & 7.839 & 2.282 & \\
Education (year) & 2.0 & 7.0 & 4.419 & 1.566 & \\
Family size (person) & 11.0 & 4.355 & 2.402 & \\
Number of beef cattle & 1.0 & 10.065 & 7.215 & \\
$\begin{array}{l}\text { Experience (year) } \\
\text { The distance between }\end{array}$ & 0 & 20 & 6.323 & 5.375 & \\
house and cowshed & & & & & \\
(meter) & & & & & \\
\hline
\end{tabular}

Based on Table 2, the highest level of biosecurity adoption is sanitation (91.6\%), followed by good management practice $(86.0 \%)$, and calf management $(65.3 \%)$. On average, the level of biosecurity adoption is $69.3 \%$, which can be categorized as a high level of adoption. This means that beef cattle farmers in Luwu regency are capable of managing their cattle. The result of this research is better than that of Lestari et al. (2014) who find that the level of biosecurity adoption by beef cattle farmers in Barru regency can be categorized as low adopters with the percentage of $47.4 \%$.

The lowest level of adoption is disease prevention, with $52.1 \%$. This indicates that most beef cattle farmers do not know how to prevent diseases. This finding is in line with that of Alemayehu and Leta (2014) who state that biosecurity measures in export- 
oriented feedlots tend to be very low, with the majority of them undertaking little or no preventive measures to combat disease transmission either within or among farms.

Table 2. Level of Biosecurity Adoption

\begin{tabular}{clc}
\hline No & Biosecurity Measures & Percentage \\
\hline 1 & Good Management Practice & 86.0 \\
2 & Sanitation & 91.6 \\
3 & Equipment & 61.3 \\
4 & Diseases & 62.1 \\
5 & Disease Prevention & 52.1 \\
6 & Calf Management & 65.3 \\
\hline & Level of Adoption & 69.3 \\
\hline
\end{tabular}

\section{CONCLUSION}

This paper investigates biosecurity adoption of beef cattle farmers in Luwu Regency, South Sulawesi, Indonesia. The result of our study suggests that the level of biosecurity adaptation in Luwu Regency are high.

\section{REFERENCES}

Alemayehu, G. and Leta, S. (2014), "Biosecurity practices in Central Ethiopian cattle feedlots: Its implication for live cattle export", International Journal of Livestock Production, Vol. 5 No. 11, pp. 181-187.

Azis, A. (2016), "Kebijakan Umum Pembangunan Peternakan dalam Mendukung Peternakan Rakyat di Sulawesi Selatan”, Seminar Nasional Peternakan, Universiatas Hasanuddin, Makassar.

Brennan, M.L. and Christley, R.M. (2013), "Cattle producers' perception of biosecurity", BMC Veterinary Research, Vol. 9 No. 71, pp. 1-8.

Lestari, V.S., Sirajuddin, S.N. and Asnawi, A. (2014), "Biosecurity adoption on cattle farms in Indonesia”, European Journal of Sustainable Development, Vol. 3 No. 4, pp. 403407.

Nuruddin. (2016), "Anthrax Masuki 5 Daerah Baru", TROBOS, available at: www.trobos.com/detail-berita/2016/11/20/55/8136/tahun-2016-anthraxmasuki-5-daerah-baru.

Rahman, S. (2007), "Adoption improved technologies by the pig farmers of Arizawi district of Mizoram, India", Livestock Research for Rural Development, available at: http://www.lrrd.org/lrrd19/1/rahm19005.htm.

Rogers, E.M. (1962), Diffusion of Innovations, Free Press of Glencoe Division of The Macmillon Co., New York.

Sahlstrom, L., Virtanen, J., Kyyro, J. and Lyytikainnen, T. (2014), "Biosecurity on Finnish cattle, pig, and sheep farms - results from a questionnaire", Preventive Veterinary Medicine, Vol. 117 No. 1, pp. 59-67.

Sihombing. (2000), Teknik Pengelolaan Limbah Kegiatan/Usaha Peternakan, Pusat Penelitian Lingkungan Hidup Lembaga Penelitian, Institut Pertanian Bogor, Bogor.

Suparta, N. and Sukanata, W. (2017), "Strategi Tata Niaga Sapi Lokal untuk Memperkuat Ekonomi Pedesaan di Indonesia”, Seminar PERSEPSI II, Denpasar. 